\title{
The spoken word
}

ORAL CULTURE IN BRITAIN,

$1500-1850$

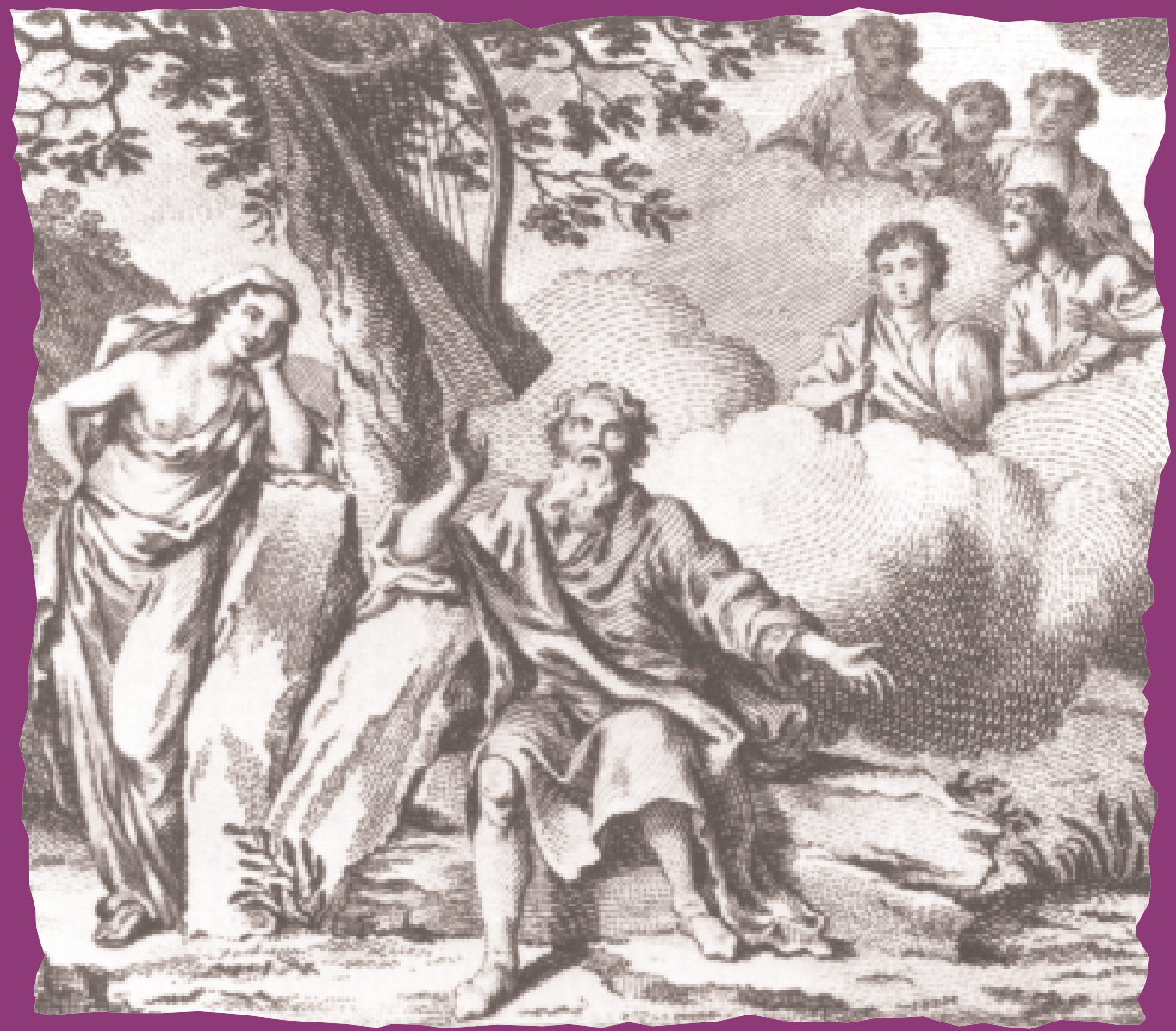

\section{A D A M F O X \& \\ D A N I L W O O L F}




\section{The spoken word}

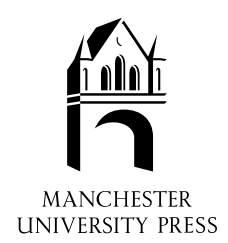


Politics, culture and society in early modern Britain

\author{
General Editors \\ PROFESSOR ANN HUGHES \\ DR ANTHONY MILTON \\ PROFESSOR PETER LAKE
}

This important series publishes monographs that take a fresh and challenging look at the interactions between politics, culture and society in Britain between 1500 and the mid-eighteenth century. It counteracts the fragmentation of current historiography through encouraging a variety of approaches which attempt to redefine the political, social and cultural worlds, and to explore their interconnection in a flexible and creative fashion. All the volumes in the series question and transcend traditional interdisciplinary boundaries, such as those between political history and literary studies, social history and divinity, urban history and anthropology. They thus contribute to a broader understanding of crucial developments in early modern Britain.

Already published in the series

Leicester and the Court: essays on Elizabethan politics SIMON ADAMS Ambition and failure in Stuart England: the career of John, first Viscount Scudamore IAN ATHERTON

The idea of property in seventeenth-century England: tithes and the individual LAU RA BRACE

Betting on lives: the culture of life insurance in England, 1695-1775 GEOFFREY CLARK Home divisions: aristocracy, the state and provincial conflict THOMAS COGSWELL

A religion of the Word: the defence of the reformation in the reign of Edward VI CATHARINE DAVIES

Cromwell's major-generals: godly government during the English Revolution CHRISTOPHER DURSTON

Urbane and rustic England: cultural ties and social spheres in the provinces, 1660-1750 CARL B. ESTABROOK

The English sermon revised: religion, literature and history, 1600-1750 LORI ANNE FERRELl and PETER MCCUllough (eds)

Londinopolis: essays in the cultural and social history of early modern London PAUL GRIFFITHS and MARK JENNER (eds)

Inventing a republic: the political culture of the English Commonwealth, 1649-1653 SEAN KELSEY

The boxmaker's revenge: 'orthodoxy', 'heterodoxy' and the politics of the parish in early Stuart London PETER LAKE

Theatre and empire: Great Britain on the London stages under James VI and I TRISTAN MARSHALL

Courtship and constraint: rethinking the making of marriage in Tudor England DIANA O'HARA

Communities in early modern England: networks, place, rhetoric ALEXANDRA SHEPARD and PHILIP WITHINGTON

Aspects of English Protestantism, c. 1530-1700 NICHOLAS TYACKE

Political passions: gender, the family and political argument in England, 1680-1714

RACHEL WEIL 


\title{
The spoken word
}

Oral culture in Britain I500-1850

\author{
edited by \\ Adam Fox and Daniel Woolf
}

\author{
Manchester \\ University Press \\ Manchester and New York
}

distributed exclusively in the USA by Palgrave 
Copyright (C) Manchester University Press 2002

While copyright in the volume as a whole is vested in Manchester University Press, copyright in individual chapters belongs to their respective authors, and no chapter may be reproduced wholly or in part without the express permission in writing of both author and publisher.

Published by Manchester University Press

Oxford Road, Manchester MI3 9NR, UK

and Room 400, I75 Fifth Avenue, New York, NY ıоoıo, USA

www.manchesteruniversitypress.co.uk

Distributed exclusively in the USA by

Palgrave, I75 Fifth Avenue, New York,

NY IooIo, USA

Distributed exclusively in Canada by

UBC Press, University of British Columbia, 2029 West Mall,

Vancouver, BC, Canada v6 T IZ2

British Library Cataloguing-in-Publication Data

A catalogue record for this book is available from the British Library

Library of Congress Cataloging-in-Publication Data applied for

ISBN $\quad$ O 7I90 57469 hardback

○ 7190 57477 paperback

First published 2002

I0 $0908070605040302 \quad$ I0 987654321

Typeset in Scala with Pastonchi display

by Carnegie Publishing, Lancaster

Printed in Great Britain

by Bookcraft (Bath) Ltd, Midsomer Norton 